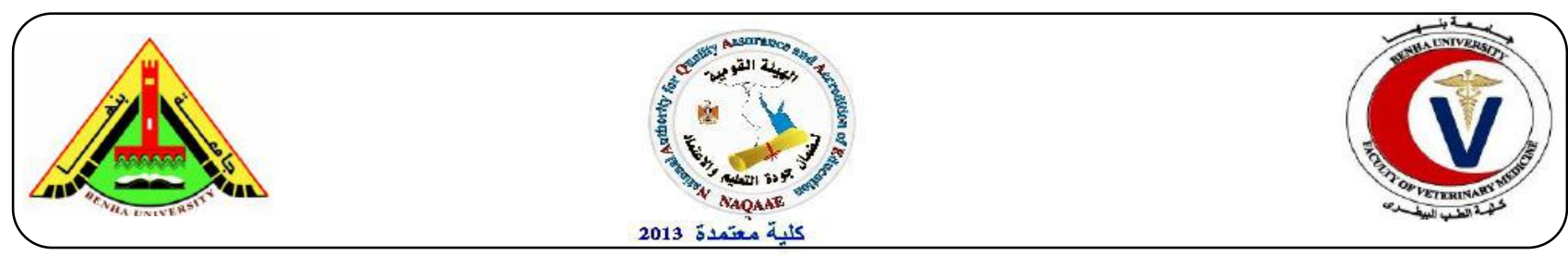

\title{
Biochemical and Histopahthological Changes on Toxoplasma Infected Rats Treated with Lincocin and/ or Green Tea
}

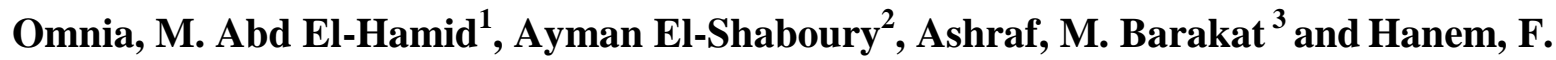 \\ Khater $^{4}$ \\ ${ }^{1}$ Biochemistry Department, Faculty of Vet. Med. Benha University, Egypt. \\ ${ }^{2}$ Biochemistry Department, Faculty of Vet. Med. Benha University, Egypt. \\ ${ }^{3}$ Zoonoses Department, National Research Center. Dokki, Giza, Egypt. \\ ${ }^{4}$ Parasitology Department, Faculty of Vet. Med. Benha University, Egypt.
}

\section{A B S T R A C T}

Toxoplasma gondii is a blood parasite of felids with a wide range of intermediate hosts including humans. The present study was carried out to evaluate the efficacy of acute toxoplasmosis on liver, kidney functions and fertility hormones of infected rats, also the effect of Lincocin and green tea oil and their combination on improving the side effects of acute infection. A total number of 40 pathogen and Toxoplasma-free Sprague-Dawley rats were divided into four groups as follows: Group (1) non infected non treated; Group (2) infected non treated, Group (3) infected and treated with Lincocin; Group (4) and infected and treated Lincocin and the addition of green tea. The recorded data revealed a significant elevation in levels of ALT, AST, T. Bilirubin, urea and creatinine and a significant decrease of the levels of albumin, progesterone, and testosterone in infected non- treated rats when compared with those of the non- infected group, while cortisol level was not affected. It could be concluded that $T$. gondii could affect liver and kidney functions and adversely affect major reproductive hormones. Therefore, it is recommended for the In Vitro Fertilization (IVF) and fertility centers to investigate $T$. gondii infection in the serum of infertile men as a routine test and treat the positive cases. Treatments with Lincocin plus green tea could be the drug of choice to avoid side effects of acute toxoplasmosis.

Keywords: Toxoplasmosis, fertility hormones, liver and kidney functions, Lincocin, green tea.

(http://www.bvmj.bu.edu.eg)

(BVMJ-35(1): 216-227, 2018)

\section{INTRODUCTION}

Toxoplasma gondii is an obligate intracellular opportunistic coccidium parasite of felids with an unusually wide range of intermediate hosts. T. gondii infections are widely prevalent in human beings and animals worldwide (Dubey, 2007). Nowadays $T$. gondii found to be worldwide in distribution, where nearly one-third of humanity has been exposed to this parasite (Tenter et al., 2000). 
The parasite is an obligate intracellular, the definitive hosts only are domestic and wild cats; in which the sexual phase of the life cycle occurs in the intestinal epithelium ended by the shedding of unsporulated oocysts in feces and the sporulation occurs outside the host. In the intermediate hosts which are either animals or man a transient acute phase caused by tachyzoites followed by the chronic phase which is characterized by formation of dormant tissue cysts contain bradyzoites. Humans become infected post-natally by ingesting tissue cysts from undercooked meat, consuming food or drink contaminated with oocysts or by accidentally ingesting oocysts from the environment. Because of its broad host range, its high infection rates and its benign co-existence with the host, $T$. gondii is regarded as one of the most successful parasites on earth.

Toxoplasma gondii is a global Parasite with no known geographical boundaries (Weiss and Dubey 2009).This high prevalence of infection in man proves the importance of toxoplasmosis as a zoonotic disease, particularly in pregnant women and immuno-compromised patients (Tenter et al., 2000).

Acute Toxoplasma infection may cause temporary hypogonadotropic gonadal insufficiency regardless of the course of the disease (Oktenli, et al, 2004). Toxoplasma infection changes the concentration of serum testosterone in mice and human rather than changed concentration of testosterone influences the probability of the Toxoplasma infection. Toxoplasmosis can affect main reproductive parameters in male rats including sperm motility, concentration and morphology, which are the most predictive of their fertilizing capacity (Terpsidis et al., 2009).

The control of $T$. gondii infection appears to be difficult under the local conditions, as most food animals easily to become infected through oocysts, which are spread from cat feces and can strongly resist the adverse environmental conditions. According to Dubey et al., (2007), the control strategies depending on carrying out hygienic measures as: preventing contamination of human and animal foods with Toxoplasma oocysts; avoid pregnant female women from contact with cats; infected meat and organs contains $T$. gondii tissue cysts must be properly cooked, freeze or cured before consumption; Finally treatment of infected animals and man especially during pregnancy may reduce the health hazardous and pathogenicity by the parasite. Some antibiotics also may reduce the hazard like Lincocin the tread name of Lincomycin which is a lincosamide antibiotic that comes from the actinomycet, Streptomyces lincolnensis (MacLeod et al,.1964) Lincomycin is a narrow spectrum antibiotic with activity against Gram-positive and cell wall-less bacteria including pathogenic species of Mycoplasma. Lincomycin is used to treat severe bacterial infections in patients who cannot use penicillin antibiotics. It is used as antimicrobial infections. Lincomycin shows weak activity against most Gram-negative bacteria. (Birkenmeyer et al., 1970).

Aim of the proposed work: the therapeutic effect of the antibiotics Lincocin and addition of green tea on infected rats with toxoplasmosis, the effect of toxoplasmosis on fertility and the efficacy of enzymes of liver and kidney of rat infected with toxoplasmosis.

\section{MATERIALS AND METHODS}

\subsection{Parasite}

Toxoplasma gondii strains (T. gondii RHHXGPRT virulent strain) or the RH strain was secured in Zoonotic Diseases Department, National Research Center, Egypt. The RH strain tachyzoites were maintained through successive intraperitoneal tachyzoites - tachyzoites passages in mice every 3 days, the obtained tachyzoites were 
used for intraperitoneal infection after counting and dilution as necessary (105-106factor dilution).

\subsection{Animals}

A total number of 40 pathogen and Toxoplasma-free Sprague-Dawley rats average body weight $125-160$ gm obtained from Laboratory Animals House, National Research Center, Dokki, Giza, Egypt; were used in the acute trials. The animals were housed in standard environmental conditions of temperature $\left(24^{\circ} \mathrm{C}\right)$ and relative humidity (50\%) with a 12:12 light: Dark cycle. with free access to a standard commercial diet and water. Experiments were performed according to the Guide for the Care and Use of Laboratory Animals and Ethical Approval of Animal Rights.

\subsection{Drugs}

\subsubsection{Lincocin}

Generic Name: Lincomycin hydrochloride ( $\mathrm{Hcl})$

Brand Name: Lincocin

Lincocin contains lincomycin hydrochloride, the monohydrated salt of Lincomycin. The chemical name for lincomycin hydrochloride is Methyl 6,8- dideoxy-6- (1-methyl-trans-4propyl L-2pyrolidinecarboxamido)-1-thio-Derythro- $\alpha$-D-galactooctopyranoside

monohydrochloride monohydrate. The molecular formula of lincomycin hydrochloride is $\mathrm{C} 18 \mathrm{H} 34 \mathrm{~N} 2 \mathrm{O} 6 \mathrm{~S} . \mathrm{HCl} . \mathrm{H} 2 \mathrm{O}$ and the molecular weight is 461.01 (Spízek and Rezanka (2004). It was purchased by Pharmacia \& Upjohn Company, Divition of pfizer Inc ,NY 10017, Pfizer an international corporation for pharmaceutical industries.

Green Tea oil:

Components:
o Volatile
oil
contains
Epigaiiocatechin_3Gaiiate.
o Penin material.
- Phenol derivatives and alkaloids.

- Caffeine 5.3\% ( Caffeine Althiovljeliyn (Theophy line) alteo Prommin (Theobromine).

C \& A vitamins and materials Afsih.

It was purchased by Cap Farm Company for oil and natural plants extraction Al Obour city ,Cairo, Egypt.

\subsection{Experimental Design}

Rats were divided into four groups (10 rats each). Each rat in groups 2-4 was injected with 1000 of tachyzoites of $T$. gondii.

- Group (Gr1) or the normal control group: Rats were non infected and non treated.

- Gr2 or the infected control group: Rats were infected and non treated.

- Gr3 or LN: Rats were infected and treated with Lincocin at dose of 150 $\mathrm{mg} / \mathrm{kg} / \mathrm{b} . \mathrm{w} /$ day for one week intraperitoneally.

- Gr4 or LN+GT: Rats were infected and treated as those of Gr3 plus the addition of green tea at dose of 150 $\mathrm{mg} / \mathrm{kg} / \mathrm{b} . \mathrm{w} /$ day orally for 3 days after injection of Lincocin.

Blood samples were collected from each group from medial canthus of the eyes and transported to unhepranized tube which allowed clotting at room temperature then sera were separated by centrifugation at $3000 \mathrm{rpm}$ for $5 \mathrm{~min}$, and frozen at $-20^{\circ} \mathrm{C}$ for further biochemical investigation (at zero time, $7^{\text {th }}, 10^{\text {th }}$, and $13^{\text {th }}$ days).

\subsection{Biochemical tests:}

Liver functions were evaluated by the estimation of the activates of serum aspartate aminotransferase (AST/ GOT) and serum alanine aminotransferase (ALT/ GPT), according to Clin, Chem (1980); serum albumin, according to Doumas et al., (1971); and total bilirubin, according to Yuong (1990). 
Kidney functions were evaluated via the estimation of creatinine, according to Siest et al., (1985) and urea, according to Batton and Crouch, (1977).

c- Hormones that estimate fertility as follows: testosterone, according to Tietz (1999); progesterone, according to Leon Speroff et al., (1999); and Cortisol, according to Gardner et al., (2011).

\subsection{Statistical analysis}

The collected, revised and verified data were analyzed by the Statistical Package for Social Science (SPSS) program, version 18.0 for Windows. Quantitative data was expressed using mean and standard deviation and analyzed using F-test (ANOVA) to compare the different studied groups.

\section{RESULTS}

Regarding hepatorenal function tests, there was a significant increase in activities of ALT, AST, T. bilirubin, urea and creatinine in the infected control group compared to those of the normal control group meanwhile, a significant decrease in serum albumin level was reported in the infected control group when compared to those of the normal control group. Treatment with Lincocin in $\mathrm{Gr} 3$ decreased $(\mathrm{P} \leq 0.05)$ the activities of ALT, AST, T. bilirubin, urea, and creatinine when compared to those of the infected control group. However serum albumin level was increased when compared to those of the infected control group. Treatment with green tea in Gr4 significantly $(\mathrm{P} \leq 0.05)$ improved the hepatorenal activities of infected rats (Table 1).

Cortisol level was not affected in all groups while a significant $(\mathrm{P} \leq 0.05)$ decrease in the levels of progesterone and testosterone was observed in the infected control group when compared to the normal control group. Treated groups (LN and $\mathrm{LN}+\mathrm{GT})$ showed significant $(\mathrm{P} \leq 0.05)$ improvements of the levels of progesterone and testosterone (Table 2).

Histopathologically, there were some of degenerated hepatocytes, showing illlocalized parasitophorous vacuoles in the ileum, complete necrosis in the lining epithelium of kidney. 
Table (1): Effect of Lincocin and green tea and their combination on the liver and kidney functions in Toxoplasma infected rats

\begin{tabular}{|c|c|c|c|c|c|c|c|c|}
\hline $\begin{array}{c}\text { Group } \\
\text { numbers }\end{array}$ & $\begin{array}{c}\text { Group } \\
\text { descriptio } \\
n\end{array}$ & $\begin{array}{c}\text { Time } \\
\text { (Days post } \\
\text { infection) }\end{array}$ & $\begin{array}{c}\text { GPT } \\
(\mathrm{ALT}) \\
(\mathrm{ul} / \mathrm{l})\end{array}$ & $\begin{array}{c}\text { GOT } \\
\text { (AST) } \\
(\mathrm{ul} / 1)\end{array}$ & $\begin{array}{c}\text { Total } \\
\text { Bilirubin } \\
(\mathrm{mg} / \mathrm{dl})\end{array}$ & $\begin{array}{l}\text { Albumin } \\
(\mathrm{g} / \mathrm{dl})\end{array}$ & $\begin{array}{l}\text { Creatinine } \\
(\mathrm{mg} / \mathrm{dl})\end{array}$ & $\begin{array}{c}\text { Urea } \\
(\mathrm{mg} / \mathrm{dl})\end{array}$ \\
\hline \multirow[t]{3}{*}{1} & \multirow[t]{3}{*}{$\begin{array}{l}\text { Normal } \\
\text { control }\end{array}$} & 0 & $\begin{array}{r}19.92 \\
\pm 0.19^{\mathrm{a}}\end{array}$ & $\begin{array}{r}19.02 \\
\pm 0.06^{\mathrm{a}}\end{array}$ & $\begin{array}{r}0.29 \\
\pm 0.01^{a}\end{array}$ & $\begin{aligned} & 3.96 \\
\pm & 0.08^{\text {b.c }}\end{aligned}$ & $\begin{array}{c}0.93 \\
\pm 0.12^{\mathrm{a}, \mathrm{b}}\end{array}$ & $\begin{array}{c}16.77 \\
\pm 0.32^{\mathrm{a}}\end{array}$ \\
\hline & & 10 & $\begin{array}{c}20.29 \\
\pm 0.59^{\mathrm{a}}\end{array}$ & $\begin{array}{c}19.28 \\
\pm 0.26^{\mathrm{a}}\end{array}$ & $\begin{array}{r}0.28 \\
\pm 0.01^{\mathrm{a}}\end{array}$ & $\begin{aligned} & 3.91 \\
\pm & 0.19^{\text {b.c }}\end{aligned}$ & $\begin{array}{c}0.80 \\
\pm 0.12^{\mathrm{a}, \mathrm{b}}\end{array}$ & $\begin{array}{c}17.10 \\
\pm 0.12^{\mathrm{a}}\end{array}$ \\
\hline & & 13 & $\begin{array}{c}21.44 \\
\pm 0.23^{\mathrm{a}}\end{array}$ & $\begin{array}{c}19.76 \\
\pm 0.23^{\mathrm{a}}\end{array}$ & $\begin{array}{c}0.30 \\
\pm 0.02^{\mathrm{a}}\end{array}$ & $\begin{aligned} & 3.96 \\
\pm & 0.33^{\text {b.c }}\end{aligned}$ & $\begin{array}{c}0.74 \\
\pm 0.08^{\mathrm{a}, \mathrm{b}}\end{array}$ & $\begin{array}{c}17.10 \\
\pm 0.12^{\mathrm{a}}\end{array}$ \\
\hline \multirow[t]{3}{*}{2} & \multirow[t]{3}{*}{ Infected } & 7 & $\begin{array}{r}75.08 \\
\pm 14.03^{c}\end{array}$ & $\begin{array}{c}123 \\
\pm 27.4^{\text {b.c }}\end{array}$ & $\begin{array}{c}2.01 \\
\pm 0.31^{c}\end{array}$ & $\begin{array}{c}3.36 \\
\pm 0.20^{\text {a.b }}\end{array}$ & $\begin{array}{c}2.11 \\
\pm 0.12^{c}\end{array}$ & $\begin{array}{r}90.20 \\
\pm 12.45^{c}\end{array}$ \\
\hline & & 10 & $\begin{array}{c}88.48 \\
\pm 4.29^{\mathrm{c}}\end{array}$ & $\begin{array}{c}188 \\
\pm 19.56^{\mathrm{d}}\end{array}$ & $\begin{array}{c}2.15 \\
\pm 0.28^{c}\end{array}$ & $\begin{array}{c}3.08 \\
\pm 0.04^{\mathrm{a}}\end{array}$ & $\begin{array}{c}2.43 \\
\pm 0.18^{\mathrm{c}, \mathrm{d}}\end{array}$ & $\begin{array}{c}111.67 \\
\pm 0.74^{\mathrm{d}}\end{array}$ \\
\hline & & 13 & $\begin{array}{c}106 \\
+3.98^{\mathrm{e}}\end{array}$ & $\begin{array}{c}297 \\
\pm 4.11^{\mathrm{e}}\end{array}$ & $\begin{array}{c}2.80 \\
\pm 0.07^{\mathrm{d}}\end{array}$ & $\begin{array}{r}2.92 \\
\pm 0.07^{\mathrm{a}}\end{array}$ & $\begin{array}{c}2.60 \\
\pm 0.12^{\mathrm{d}}\end{array}$ & $\begin{array}{r}118.49 \\
\pm 0.54^{\mathrm{d}}\end{array}$ \\
\hline \multirow[t]{2}{*}{3} & \multirow[t]{2}{*}{ LN } & 10 & $\begin{array}{c}54.79 \\
\pm 5.77^{\mathrm{c}}\end{array}$ & $\begin{array}{c}238 \\
\pm 15.82^{\mathrm{d}}\end{array}$ & $\begin{array}{c}0.78 \\
\pm 0.02^{b}\end{array}$ & $\begin{array}{c}4.22 \\
\pm 0.39^{\text {c.d }}\end{array}$ & $\begin{array}{c}0.67 \\
\pm 0.02^{a}\end{array}$ & $\begin{array}{c}37.49 \\
\pm 3.26^{\mathrm{b}}\end{array}$ \\
\hline & & 13 & $\begin{array}{c}55.39 \\
\pm 3.75^{\mathrm{c}}\end{array}$ & $\begin{array}{c}317 \\
\pm 13.4^{\mathrm{e}}\end{array}$ & $\begin{array}{c}0.76 \\
\pm 0.06^{\mathrm{b}}\end{array}$ & $\begin{array}{c}4.95 \\
\pm 0.05^{\mathrm{d}}\end{array}$ & $\begin{array}{c}1.08 \\
\pm 0.20^{\mathrm{d}}\end{array}$ & $\begin{array}{r}78.60 \\
\pm 4.73^{c}\end{array}$ \\
\hline 4 & $\mathrm{LN}+\mathrm{GT}$ & 13 & $\begin{array}{c}45.02 \\
\pm 3.64^{\mathrm{b}}\end{array}$ & $\begin{array}{c}255 \\
\pm 18.00^{\mathrm{f}}\end{array}$ & $\begin{array}{c}0.74 \\
\pm 0.04^{\mathrm{a}}\end{array}$ & $\begin{array}{c}4.63 \\
\pm 0.10^{\mathrm{d}}\end{array}$ & $\begin{array}{r}1.07 \\
\pm 0.07^{\mathrm{c}, \mathrm{d}}\end{array}$ & $\begin{array}{c}35.54 \\
\pm 2.24^{b}\end{array}$ \\
\hline
\end{tabular}

Data was represented as Mean \pm Standard error (S.E); LN= Rats were infected and treated with lincocin at dose of $150 \mathrm{mg} / \mathrm{kg} / \mathrm{b} . w /$ day for one week.; LN+ GT = Rats were infected and treated as those of Gr. 3 plus the addition of green tea at dose of $150 \mathrm{mg} / \mathrm{kg} / \mathrm{b}$.w/day orally for 3 days after injection of Lincocin.

Values within a column followed by different uppercase letters were significantly different $(\mathrm{P} \leq 0.05)$, while values within a column followed by the same uppercase letters were not significantly different $(\mathrm{P} \leq 0.05)$. 
Table (2): Effect of Lincocin \& green tea on the fertility hormones in Toxoplasma infected rats

\begin{tabular}{|c|c|c|c|c|c|}
\hline $\begin{array}{c}\text { Group } \\
\text { numbers }\end{array}$ & $\begin{array}{c}\text { Group } \\
\text { description }\end{array}$ & $\begin{array}{c}\text { Time } \\
\text { (Days post } \\
\text { infection) }\end{array}$ & $\begin{array}{l}\text { Progesterone } \\
\quad(\mathrm{ng} / \mathrm{dl})\end{array}$ & $\begin{array}{l}\text { Cortisol } \\
\text { (ug/dl) }\end{array}$ & $\begin{array}{c}\text { Testosterone } \\
\text { (ng/dl) }\end{array}$ \\
\hline \multirow[t]{3}{*}{1} & \multirow[t]{3}{*}{$\begin{array}{l}\text { Normal } \\
\text { control }\end{array}$} & 0 & $\begin{array}{c}24.67 \\
\pm 0.88^{\text {e }}\end{array}$ & $\begin{array}{c}7.90 \\
\pm 0.81^{a}\end{array}$ & $\begin{array}{c}173 \\
\pm 3.53^{d}\end{array}$ \\
\hline & & 10 & $\begin{array}{c}23.67 \\
\pm 1.20^{\mathrm{e}}\end{array}$ & $\begin{array}{c}7.49 \\
\pm 0.85^{\mathrm{a}}\end{array}$ & $\begin{array}{l}174 \\
\pm 3.61\end{array}$ \\
\hline & & 13 & $\begin{array}{c}23.27 \\
\pm 1.13^{\mathrm{e}}\end{array}$ & $\begin{array}{c}7.81 \\
\pm 0.23^{a}\end{array}$ & $\begin{array}{c}173 \\
\pm 3.79^{d}\end{array}$ \\
\hline \multirow[t]{3}{*}{2} & \multirow[t]{3}{*}{ Infected } & 7 & $\begin{array}{c}9.00 \\
\pm 0.41^{b}\end{array}$ & $\begin{array}{r}7.02 \\
\pm 0.91^{\mathrm{a}}\end{array}$ & $\begin{array}{c}151 \\
\pm 1.45^{\mathrm{a}}\end{array}$ \\
\hline & & 10 & $\begin{array}{c}5.63 \\
\pm 0.59^{a}\end{array}$ & $\begin{array}{c}7.17 \\
\pm 0.75^{\mathrm{a}}\end{array}$ & $\begin{array}{c}149 \\
\pm 1.76^{\mathrm{a}}\end{array}$ \\
\hline & & 13 & $\begin{array}{c}4.68 \\
\pm 0.34^{\mathrm{a}}\end{array}$ & $\begin{array}{c}7.72 \\
\pm 0.48^{a}\end{array}$ & $\begin{aligned} & 147 \\
\pm & 2.33^{\mathrm{a}}\end{aligned}$ \\
\hline \multirow[t]{2}{*}{3} & \multirow[t]{2}{*}{$\mathrm{LN}$} & 10 & $\begin{array}{r}16.53 \\
\pm 0.57^{c}\end{array}$ & $\begin{array}{c}7.63 \\
\pm 0.75^{\mathrm{a}}\end{array}$ & $\begin{array}{c}160 \\
\pm 1.45^{b}\end{array}$ \\
\hline & & 13 & $\begin{array}{c}18.51 \\
\pm 0.35^{\mathrm{c}, \mathrm{d}}\end{array}$ & $\begin{array}{c}7.76 \\
\pm 0.74^{\mathrm{a}}\end{array}$ & $\begin{array}{c}168 \\
\pm 3.22^{\mathrm{b}, \mathrm{c}, \mathrm{d}}\end{array}$ \\
\hline 4 & $\mathrm{LN}+\mathrm{GT}$ & 13 & $\begin{array}{c}18.90 \\
\pm 0.31^{\mathrm{c}, \mathrm{d}}\end{array}$ & $\begin{array}{c}7.00 \\
\pm 0.57^{\mathrm{a}}\end{array}$ & $\begin{array}{c}168 \\
\pm 3.31^{\mathrm{c}, \mathrm{d}}\end{array}$ \\
\hline
\end{tabular}

Data was represented as Mean \pm Standard error (S.E); LN= Rats were infected and treated with lincocin at dose of $150 \mathrm{mg} / \mathrm{kg} / \mathrm{b} . w /$ day for one week.; $\mathrm{LN}+\mathrm{GT}=$ Rats were infected and treated as those of Gr. 3 plus the addition of green tea at dose of $150 \mathrm{mg} / \mathrm{kg} / \mathrm{b}$.w/day orally for 3 days after injection of Lincocin.

Values within a column followed by different uppercase letters were significantly different $(\mathrm{P} \leq 0.05)$, while values within a column followed by the same uppercase letters were not significantly different $(\mathrm{P} \leq 0.05)$. 


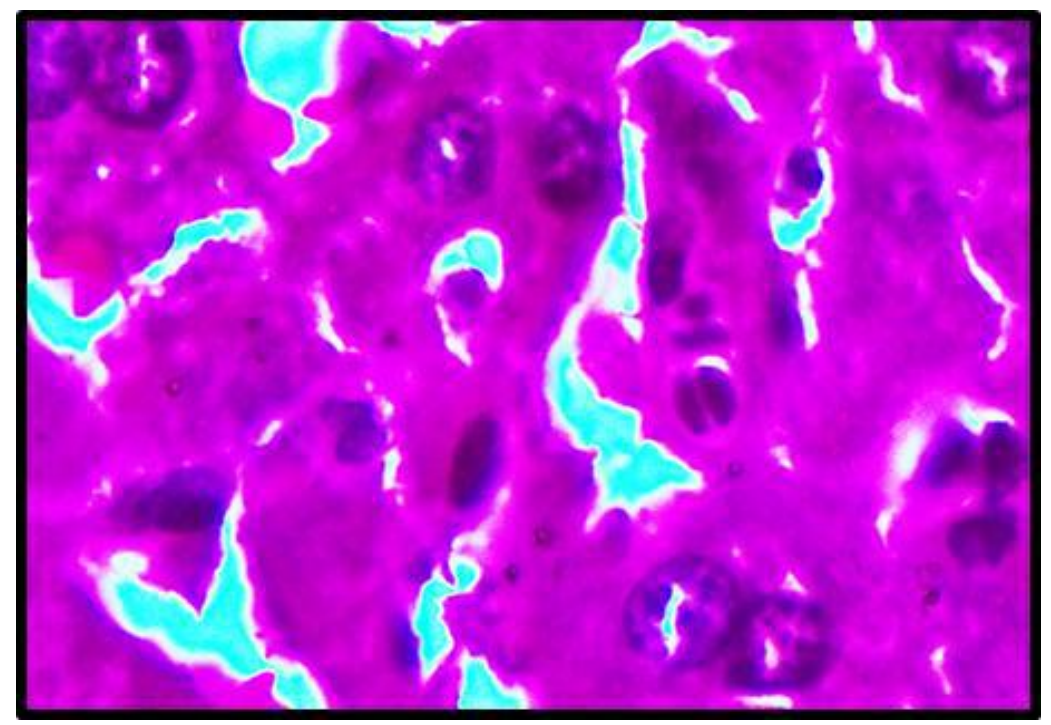

(Fig.1): Liver of rats infected with RH virulent strain showed presence of tachyzoites showed the presence of small numbers of tachyzoites appeared as pseudo cyst of $T$. gondii among some of degenerated hepatocytes (arrow) (X 1000).

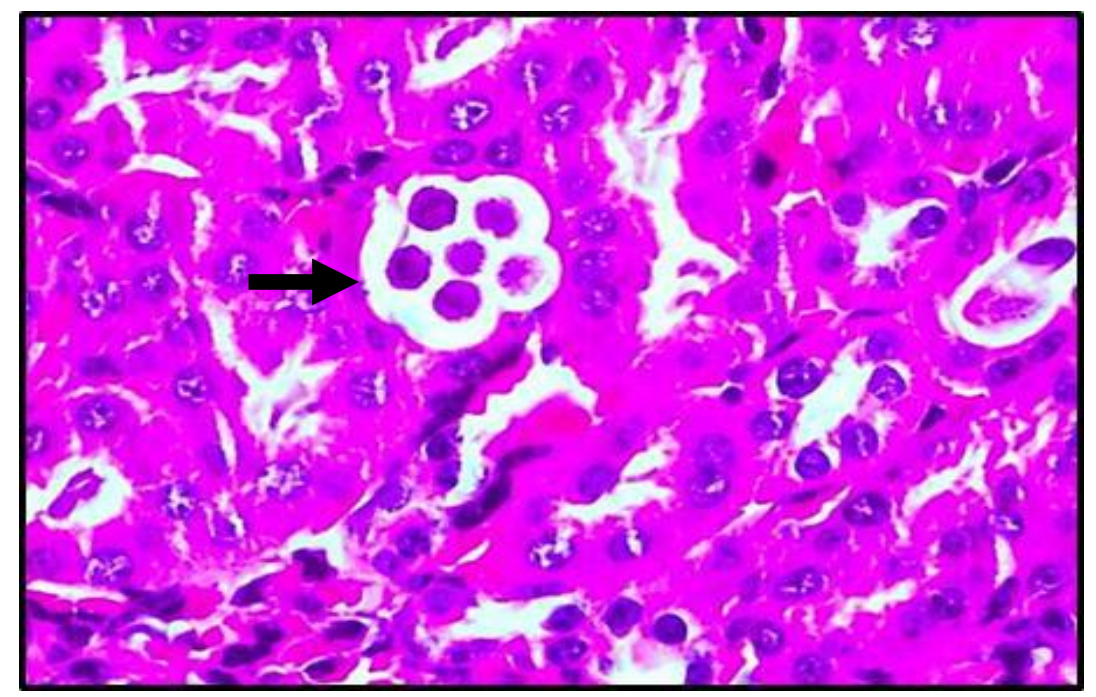

(Fig.2): Kidney of rats intraperitoneally injected with $T$. gondii strain revealed the presence of multiple T. gondii tissue cysts in the lumen of proximal convoluted tubules (arrow) associated with complete necrosis in their lining epithelium (X 400).

\section{DISCUSSION}

Toxoplasmosis as a zoonosis disease became a major clinical problem worldwide (Aubert et al., 2000). In the present study, we tested the biochemical and histopathological changes on toxoplasma infected rats treated with Lincocin and/ or green tea. Rats were used as they have been used as an animal model for $T$. gondii infection in humans who also show a high degree of resistance to its pathogenic effects (Fayed et al., 2004).
Our data indicated that toxoplasmosis adversely affected both liver and kidney functions which represented as increased levels of Total bilirubin, ALT, AST activities, Creatinine and Urea levels and a decreased level of albumin. Such results were in agreement with those of Al-Jowari and Hussein (2014), and Portugal et al. (2004). On the other hand, our data disagree with those reported by El Shazly et al., (2001) and 
Ustun et al., (2004) who recorded nonsignificant differences in the severity of liver damage between the infected and noninfected rats, in which they found nonsignificant differences in the levels of Total bilirubin, ALT, AST activities, and albumin.

A decrease of serum albumin in the acute stage in the present study indicates decrease in protein metabolism or increase catabolism (Boothroyd et al., 1997), The accompanied titers appeared to rise almost parallel with the rise in serum gamma globulins (Torda, 2001). Our data regarding liver and kidney functions could be explained as toxoplasmosis causes extensive and progressive damage to the liver, remarkable proliferation of organisms. Such damage in the liver brought about changes in the liver metabolism (Montoya and Liesenfeld, 2004). Changes of protein fractions, AST, ALT varied according to the qualitative difference in intensity of inflammation by strains of Toxoplasma and host (Al-Kaissy et al., 2010).

Although the relation of enzymatic host cell and organism has been stated in varies reports (Elamin et al., 1992). Remarkable changes of enzymes in sera showed a tendency to increase after infection which might reflect the degree of damage of liver, albumin production in the reticuloendothelial tissue of the liver, kidney and gamma globulin in some tissues (Al-Kaissy et al., 2011).

Concerning fertility hormones, the present study reflected a significant $(\mathrm{P} \leq 0.05)$ decrease in levels of progesterone and testosterone levels. Similar results suggest that $T$. gondii infection can cause temporary impairment on the reproductive parameters of human or animal male as well as impairment of different hormones which may cause insufficient male reproductively (Abdol Dalimi et al., 2012).

Comparable results for progesterone had been reported (Aiumalamai et al., 1990, Al-
Warid and Al-Qadhi, 2012). Although progesterone did not regulate the replication of the parasites (María Ramírez et al., 2014), low levels of progesterone and estrogens could be accompanied with severe infection in pregnant women with acute toxoplasmosis (Al-Warid and Al-Qadhi, 2012).

Similar to progesterone, testosterone levels were also decreased in the present work. This result disagree with the results of Shirbazou et al., (2011) on infected human and agree with other results recorded on infected rabbits (Barakat 2007) and mice (Kankova et al. 2011). Another study was in agreement with our study by Sun et al., (2008) who reported that acute toxoplasmosis affects the reproductive function of male mice. Such result could be explained as the acute infection by this parasite in human-produced temporary hypogonadotropic gonadal insufficiency (Oktenli et al., 2004) and it could be an adaptive response of infected mice to Toxoplasma induced immunosuppression and the infected mice could partly compensate the latent toxoplasmosis-associated down-regulated cellular immunity.

Also, the present study revealed that, there were no changes in cortisol level in rats infected with acute Toxoplasma gondii which exhibited no changes all over the experiment when compared with normal control group. These agree with María Ramírez et al., (2014). Our study disagreed with one study (Shirbazou et al., 2011); which showed that a direct relation between the raise of Toxoplasma infection and cortisol is exist and testosterone would increases in both men and women.

Pathological changes:

There were some of degenerated hepatocytes, showing ill-localized parasitophorous vacuoles in the ileum, complete necrosis in the lining epithelium of kidney in figures (1\&2). Our result was 
agreed with El-Fadaly et al., (2015). Similar to our results were reported by Breno et al., (2015), Hazroglu et al., (2003), and Hassanain et al., (2012), who reported that, presence of tissue cysts, and could be related to penetration of acute toxoplasmosis, that rapidly multiply by endodyogeny in nucleated host cells.

Another study (Qi et al., 2005) and (Zare, et al., 2006) was in agreement with the current study results, in which it was found pathological changes in the testes, epididymis, vas deferens, prostate and thalamus of male mice with experimentally-induced acute $T$. gondii infection and they concluded that acute infection can cause infertility.

Also showed that the antibiotic Lincocin is slightly active against $T$. gondii tachyzoites in vitro Lincomycin is used to treat severe bacterial infections in patients who cannot use penicillin antibiotics. It is used as antimicrobial infections. Lincomycin shows weak activity against most Gram-negative bacteria. Spízek and Rezanka (2004) stated that chlorinated lincomycin analogues can antagonist acute toxoplasmosis in mice.

Treated groups in this study (LN and $\mathrm{LN}+\mathrm{GT})$ showed significant $(\mathrm{P} \leq 0.05)$ improvements of the hepatorenal activities as well as levels of progesterone and testosterone in infected rats. This study is in agreement with another study (Ryu 1982) which Prophylactic effect of tea on pathogenic microorganism infections to humans and animals. Protozoacidal effect on Toxoplasma gondii in vitro and mice (Chow et al., 2003).

Another study (Seung et al., 2006) and (Fukushima et al., 2009) was in agreement with the current study results, in which it was found that green tea has a prophylactic medication that has been used to control and prevent coccidiosis. Even though green tea induced a significant positive effect on the liver and kidney functions, it did not affect the levels of fertility hormones (Boehm et al., 2015).

\section{CONCLUSION}

Acute infection of $T$. gondii could affect the liver and kidney functions and adversely affect the reproductive hormones. Therefore, it is recommended for the In Vitro Fertilization (IVF) and fertility centers to investigate $T$. gondii infection in the serum of infertile men as a routine test and treat the positive cases. Treatments with Lincocin plus green tea could be the drug of choice to avoid side effects of acute toxoplasmosis.

\section{REFERENCES}

Abdoli A, Dalimi A, Movahedin M. (2012): Impaired reproductive function of male rats infected with Toxoplasma gondii. Andrologia.;44 Suppl 1:679-87.

Aiumalamai, S., Fredriksson, G., Uggla, A., Kindahl, H., and Edquist, L. (1990). The effect of Toxoplasrna gondii Infection in Flunixin Meglumine Treated Pregnant Ewes as Monitored by Plasma Levels of 15Ketodihydroprostaglandin $\quad$ F2a, progeterone, Oestrone Sulphate and Ultrasound Scanning. J. Vet. Med. 37, 23-34. doi: 10.1111/j.14390442.1990.tb00872.x.

Al-Jowari and Hussein (2014): Effect of Toxoplasmosis Infection on Liver and Kidney Functions among Pregnant Women in Abo-Gharib District- Iraq.

Al-Kaissy, A. M., Eid, R. A. A. and Fahmy, B. G. A. (2010). Biochemical studies on the effect of Toxoplasma infection on liver and kidney functions in mice. Egypt. J. Comp. Path. \& Clinic.Path., 23( 1), pp: 174 - 185.

Al-Kaissy, A.M. (2011). Biochemical Study on the Effect of Toxoplasma Infection on Liver and Kidney Function in Albino 
Mice. Al-Ma'mon College J., 18-E, pp: $120-127$.

Al-warid, H. S., and Al-qadhi, B. N. (2012). Evaluation of progesterone and estrogen hormonal levels in pregnant women with toxoplasmosis. Eur. J. Sci. Res. 91, 515-519.

Aubert, D.G., I. Maine, J.C. Villena, L. Hunt, M. Howard, S. Sheu, L.E. Brojanac, S.F. Chovan and J.M. Nowlan, 2000. Recombinant antigens to detect Toxoplasma gondii-specific immunoglobulin $\mathrm{G}$ and immunoglobulin $\mathrm{M}$ in human sera by enzyme immunoassay. J. Clin. Microbiol., 38: 1144-1150.

Barakat, A.M.A. (2007): Some diagnostic studies on male New Zealand rabbit experimentally infected with Toxoplasma gondii strain. Global Veterinaria. Vol.1(1):pp 17-23.

Batton, C.J. and Crouch, S.R. (1977): "Spectrophotometer investigation of urea." Anal Chem., 49: 464-469.

Birkenmeyer, R. D.; Kagan, F. (1970). "Lincomycin. XI. Synthesis and structure of clindamycin, a potent antibacterial agent". Journal of Medicinal Chemistry. 13 (4): 616-619. doi:10.1021/jm00298a007. PMID 4916317.

Boehm K, Borrelli F, Ernst E, et al. (2015): Green tea (Camellia sinensis) for the prevention of cancer. Cochrane Database of Systematic Reviews.

Boothroyd, J.; Black, M.; Bonnefoy, S.; Hehl, A.; Manger, I. and Tomavo, S. (1997): Genetic and biochemical analysis of development in Toxoplasma gongdii. Phil. Trans. R. Scotland, 352: 13471354.
Breno Veloso Pinheiroa, Maria de Lourdes Meirelles Noviellob, Mariana Maciel Cunhaa, Alice Thomaz Tavaresa, Ana Carolina Aguiar Vasconcelos Carneiroa, Rosa Maria Esteves Arantesb, and Ricardo Wagner AlmeidaVitor (2015): Pathological changes in acute experimental toxoplasmosis with Toxoplasma gondii strains obtained from human cases of congenital disease.

Carneiro, A. P. M.; Pascoal, L. A. F.; Watanabe, P. H.; Santos, I. B.; Lopes, J. M.; Arruda, J. C. B., 2009. Babassu meal in finishing broiler fodder: performance, carcass yield and economical evaluation. Ciência Anim. Bras., 10 (1): 40-47.

Chow, H. H., Cai, Y., Hakim, I. A., Crowell, J. A., Shahi, F., Brooks, C. A., Dorr, R. T., Hara, Y., and Alberts, D. S.( 2003): Pharmacokinetics and safety of green tea polyphenols after multiple-dose administration of epigallocatechin gallate and polyphenon $\mathrm{E}$ in healthy individuals. Clin Cancer Res. 8-15;9(9):3312-3319.

Doumas, B. T.; Watson, W.A. and Biggs, H.G. (1971): "Albumin standard and the measurements of serum albumin with bromocresol green." Clin. Chem. Acta, 31: 87.

Dubey JP (2004): Toxoplasmosis - a waterborne zoonosis. Veterinary. Animal Parasitic Diseases Laboratory, United States Department of Agriculture, Agricultural Research Service, Animal and Natural Resources Institute, BARC-East, Building 1001, 10300 Baltimore Avenue, Beltsville, MD 20705-2350, USA.

Dubey JP (2007): The History and Life Cycle of Toxoplasma gondii. In: Weiss LM, 
Kim K, editors. Toxoplasma gondii the model apicomplexan: perspectives and methods. Academic Press; London:. pp. $1-17$.

Elamin, E.A.; Elias, S.; Daugschies, A. and Rommel, M. (1992): Prevalence of Toxoplasma gondii antibodies in pastoral camels (Camelus dromedarius) in the Butana plains, midEastern Sudan. Vet. Parasitol. 43 (3-4): 171-175.

El-Fadaly, Barakat, A.M.A, Abd El-Razik (2015): Zoonotic and histo-pathological aspects of various toxoplasma gondii strains in female rats 3238 .

El-Shazly, A.M.; Soliman, M.; El-Kalla, M.R.; Rezk, H., El-Nemr, H.; Hgoussa, A. E.; El-Aaty, H. E. and Morsy, T. A. (2001) : Evaluation of soluble adhesion molecules in the diagnosis of amoebiasis, giardiasis and toxoplasmosis . 31 (3): 691-700.

Fayed, H. M.; Allam, K. A. and Ali, N.E. (2004): Merogony of Toxoplasma gondii (Apicomplexa: Coccidia) and its effect on the mortality and histopathology in the house mouse Mus musculus. J Egypt Soc Parasitol., 34(1): 45-64.

Fukushima, Y., Ohie, T., Yonekawa, Y., Yonemoto, K., Aizawa, H., Mori, Y., Watanabe, M., Takeuchi, M., Hasegawa, M., Taguchi, C., and Kondo, K. (2009): Coffee and green tea as a large source of antioxidant polyphenols in the Japanese population. $\mathrm{J}$ Agric.Food Chem. 2-25-57(4):12531259.

Gardner, D. G., Shoback, D. M., and Greenspan, F. S. (2011). Basic and Clinical Endocrinology. New York, NY: McGraw-Hill Medical.

Hassanain, M .A, El-Fadaly, H.A., Shaapan, R.M., Hassanain, N.A. and Barakat,
A.M.(2012): Biological Assay of Toxoplasma gondii Egyptian Mutton Isolates. International Journal of Zoological Research 7 (4): 330-337.

Haziroglu, R.,Altintas, K.,Atasever, A.,Glulbahar, M.Y. and Recai Tunca, O.K. (2003). "Pathological and immunological studies in rabbits experimentally infected with Toxoplasma gondii." Turk. J. Anim. Sci. 27:285-293.

Kankova, S.; Kondym, P. and Flegr, J. (2011): Direct evidence of Toxoplasma induced changes in serum testosterone in mice. Exp. Parasitol., Vol.128: pp181-183,

Leon Speroff, Robert H. Glass, Nathan G. Kase, Lippincott Williams \& Wilkins (1999): Clinical Gynecologic Endocrinology and Infertility 6th ed.

MacLeod AJ, Ross HB, Ozere RL, Digout G, van Rooyen CE (1964). "Lincomycin: A New Antibiotic Active Against Staphylococci and Other Gram-Positive Cocci: Clinical and Laboratory Studies". Can Med Assoc J. 91: 105660. PMC 1928283 . PMID 14217764.

María Ramírez, Adrián Fernando GutiérrezMaldonado , Fabiola Grijalva and Judith Jiménez (2014): The role of hormones on Toxoplasma gondii infection: a systematic review. doi: 10.3389/fmicb.00503.

Montoya, J. and Liesenfeld, O. (2004). "Toxoplasmosis". Lancet., 363 (9425), pp: 1965-1976.

Oktenli C, Doganci L, Ozgurtas T, Araz RE, Tanyuksel M, Musabak U, et al. (2004): Transient hypogonadotrophic hypogonadism in males with acute toxoplasmosis: suppressive effect of interleukin-1 beta on the secretion of 
GnRH. Hum Reprod.;19(4):859-66. Parasitology, 126: 57-72.

Portugal, L.R.; Femanries, L.R.; Cesar, Ge; Santiaçjjç, Oliveira, D.R.; Silva, N.M.; Silva, A.A.; Gazzinelli, R.T. and AlvarezLeite, J.I.. (2004): Infection with Toxoplasma gondli increases atherosclerotic lesion in Apo E-deficient mice. Infect Immun., 76 (6): 6571-5676.

Qi, R., Su, X.P., Gao, X.L., Liang, X.L., (2005): Toxoplasma infection in males with sterility in Shenyang, China (In Chinese with English abstract). Zhonghua Nan Ke Xue 11, 503-504.

Ryu, E., (1982): Prophylactic effect of tea on pathogenic microorganism infections to humans and animals. II. Protozoacidal effect on Toxoplasma gondii in vitro and mice. Int. J. Zoonoses 9, 126-131.

Seung I. Jang., Moo-Hyung Jun., Hyun S. Lillehoj., Rami A. Dalloul., Il-Keun Kong., Suk Kim ., Wongi Min (2006): Anticoccidial effect of green tea-based diets against Eimeria maxima.

Shirbazou, S.; Abasian, L. and Talebi Meymand, F. (2011) Effects of Toxoplasma gondii infection on plasma testosterone and cortisol level and stress index on patientsreferred to Sina hospital Tehran. Jundishapur J. Microbiol.,Vol. 4(3):pp 167-173.

Siest, G.; Schiele, F. and Young, D.S. (1985): "Kinetic determination of creatinine." Interpretation of Clin. Lab. Tests, p., 220-234.

Spízek J، Rezanka T (2004). "Lincomycin, cultivation of producing strains and biosynthesis". Appl. Microbiol. Biotechnol. 63 (5): 510-9. PMID 14593504. doi:10.1007/s00253-0031431-3.

SPSS for windows Release 14.0.0, 12 June, 2006. Standard Version, Copyright
SPSS. Suzuki, N. (1971): Biochemical observation on rats infected with Toxoplasma gondii. Res. Bull. Obihiro. Univ., 7: 15-25.

Sun, L.H., Fan, F., Wang, J.J., Gong, J., (2008): Acute Toxoplasma gondii infection affects the reproductive function of male mice. Zhonghua Nan Ke Xue 14, 55-57.

Tenter, A.M.; Heckeroth, A.R. and Weiss, L.M. (2000): Toxoplasma gondii: from animals to humans. Int. J. Parasitol.,Vol. 30: pp1217-1258,

Terpsidis KI, Papazahariadou MG, Taitzoglou IA, Papaioannou NG, Georgiadis MP,( 2009): Theodoridis IT. Toxoplasma gondii: reproductive parameters in experimentally infected male rats. Exp Parasitol.;121(3):238-41.

Tietz, N. W. 1999. Text book of clinical chemistry, 3rd Ed. Burtis, C. A. and Ashwood, E. R. Saunders: pp:652 657.

Torda, A. (2001): Toxoplasmosis. Are cats really the source? Aust. Fam. Physician, 30 (8): 743-747.

Ustun, S.; Aksov, U. and Daqci, F. (2004): "Incidence of toxoplasmosis in patients with cirrhosis." World J Gastroenterol., 10 (3): 452-454.

Weiss LM, Dubey JP. (2009): Toxoplasmosis: A history of clinical observations. Int $J$ Parasitol.; 39(8):895-901.

Zare F, Dalimi A, Ghaffarifar F. (2006): Detection of active Toxoplasma godii (RH strain) in the different body tissues of experimentally infected rats. Modares J Med Sci. 2006; 9(1):19-23. 